\title{
Lip and Oral Cavity Cancer pNX TNM Finding v8
}

National Cancer Institute

\section{Source}

National Cancer Institute. Lip and Oral Cavity Cancer pNX TNM Finding v8. NCI

Thesaurus. Code C132702.

Lip and oral cavity cancer in which the regional lymph nodes cannot be assessed. (from AJCC 8th Ed.) 